\title{
Influence of Aggregate Gradation on the Engineering Properties of Lightweight Aggregate Concrete
}

\author{
How-Ji Chen ${ }^{1}$ and Chung-Hao $\mathrm{Wu}^{2, *}$ iD \\ 1 Department of Civil Engineering, National Chung-Hsing University, No.250, Kuo Kuang Road, \\ Taichung 402, Taiwan; hojichen@nchu.edu.tw \\ 2 Department of Civil Engineering, Chienkuo Technology University, No.1, Chiehshou North Road, \\ Chunghau City 500, Taiwan \\ * Correspondence: chw@ctu.edu.tw; Tel.: +886-4-7111111 (ext. 3428)
}

Received: 29 July 2018; Accepted: 6 August 2018; Published: 8 August 2018

\begin{abstract}
Expanded shale lightweight aggregates, as the coarse aggregates, were used to produce lightweight aggregate concrete (LWAC) in this research. At the fixed water-cement ratio, paste quantity, and aggregate volume, the effects of various aggregate gradations on the engineering properties of LWAC were investigated. Comparisons to normal-weight concrete (NWC) made under the same conditions were carried out. From the experimental results, using normal weight aggregates that follow the specification requirements (standard gradation) obtained similar NWC compressive strength to that using uniform-sized aggregates. However, the compressive strength of LWAC made using small uniform-sized aggregates was superior to that made from standard-grade aggregates. This is especially conspicuous under the low water-cement ratio. Even though the workability was affected, this problem could be overcome with developed chemical additive technology. The durability properties of concrete were approximately equal. Therefore, it is suggested that the aggregate gradation requirement of LWAC should be distinct from that of NWC. In high strength LWAC proportioning, following the standard gradation suggested by American Society for Testing and Materials (ASTM) is optional.
\end{abstract}

Keywords: lightweight aggregates; aggregate gradation; standard gradation; uniform-sized aggregates; compressive strength; durability

\section{Introduction}

Generally, normal-weight concrete (NWC) aggregate gradation should fit in with the standard code requirements. The main purpose is to enable finer concrete workability and make the aggregate collection tighter. A tighter aggregate collection indicates that the concrete contains more aggregate and less paste. Hence, the unit weight and achievable concrete strength can be higher. Lightweight aggregate concrete (LWAC) mix-proportion design criteria is established in many standard specifications, such as ACI 318 of US, DIN of Germany, JIS of Japan, CNS 12891 of Taiwan, etc. In addition to lightweight aggregate (LWA) consideration, the aggregate gradation is generally in accordance with NWC [1-3]. For example, the criteria for the structural aggregate gradation of the structural LWAC in the American Society for Testing and Materials (ASTM) C330 specification refer to the ASTM C33 specification. The gradation prescriptions for "Lightweight aggregates for structural concrete" from CNS 3691 in Taiwan is similar to that for "Concrete aggregates" in CNS 1240 for NWC. However, for LWAC, when a higher quantity or coarser aggregate particle size is used, the unit weight of the concrete could be reduced, but negative effects on the concrete strength might occur.

Over the past decades, a number of experimental research projects have been conducted to study the properties of LWA, as well as the associated engineering properties of LWAC. They indicated that the engineering properties of LWAC are affected by several parameters, like the water-to-cement ratio, 
age, curing conditions, strength and elastic modulus of the aggregate, aggregate types, volume fraction of the aggregate, etc. [4-8]. In recent years, analytical methods of data-driven models have also been of increasing interest in evaluating the concrete compressive strength such as artificial intelligence based techniques like artificial neural network $[9,10]$ and adaptive network-based fuzzy inference systems (ANFIS) [11,12]. However, these studies do not distinctly study the effect of LWA aggregate gradation. Therefore, whether the gradation prescriptions for LWAC should parallel that for NWC or not should be further investigated. This research manufactured concrete using various aggregate grades. The engineering properties were determined to investigate the effects of various aggregate grades on concrete properties.

\section{Experimental Details}

Artificial lightweight aggregates and natural normal weight aggregates were used to manufacture concrete in this research. The test materials included clean water, Type I Portland cement of Taiwan Cement Company (specific gravity $=3.15$ ), normal weight coarse aggregates from a local river of Taichung City in Taiwan (specific gravity $=2.65$, water absorption $=1.1 \%$ ), normal weight fine aggregates (Taichung City, Taiwan) (specific gravity $=2.61$, water absorption $=1.2 \%$ ), and expanded shale lightweight aggregates (Figure 1), which were supplied from TianJin BaoMing Co., Ltd. of China. Three lightweight aggregates grades with uniform size were selected. The nominal grain sizes were $16 \mathrm{~mm}, 11 \mathrm{~mm}$ and $7 \mathrm{~mm}$. A standard gradation fit with the ASTM C330 specification was used as the control batch. The maximum grain size was $19 \mathrm{~mm}\left(\mathrm{D}_{\max }=19 \mathrm{~mm}\right)$. The basic properties of lightweight aggregates are shown in Table 1 . To obtain concretes with similar unit weight, selected lightweight aggregates from each grain size possess similar specific gravity and water absorption. In addition, the specific surface area (SSA = surface area of aggregates/volume of aggregates) defined by Singh [13] was treated as an index of the aggregates grade. The SSA of three uniform-sized aggregates and the standard aggregate grades were calculated. The amount of aggregate for each grade and the SSA calculation are shown in Table 2. The relationship between the nominal grain size and aggregates SSA is drawn in Figure 2.

Table 1. Basic properties of lightweight aggregates.

\begin{tabular}{cccc}
\hline Grain Size (mm) & Nominal Grain Size $(\mathbf{m m})$ & Particle Density $\mathbf{( k g / \mathbf { m } ^ { \mathbf { 3 } } )}$ & $\mathbf{2 4} \mathbf{~ h}$ Water Absorption (\%) \\
\hline $12.5-19$ & 16 & 1460 & 8.77 \\
$9.5-12.5$ & 11 & 1460 & 8.00 \\
$4.75-9.5$ & 7 & 1490 & 7.12 \\
\hline
\end{tabular}

Table 2. Gradation and specific surface area (SSA) of coarse aggregates.

\begin{tabular}{|c|c|c|c|c|}
\hline \multirow{2}{*}{ Gradation } & \multicolumn{3}{|c|}{ Amount (\%) } & \multirow{2}{*}{$\operatorname{SSA}\left(\mathrm{m}^{2} / \mathrm{m}^{3}\right)$} \\
\hline & $19-12.5 \mathrm{~mm}$ & $12.5-9.5 \mathrm{~mm}$ & $9.5-4.75 \mathrm{~mm}$ & \\
\hline Standard gradation (S) & 40 & 30 & 30 & 573 \\
\hline Nominal grain size $16 \mathrm{~mm}$ & 100 & 0 & 0 & 381 \\
\hline Nominal grain size $11 \mathrm{~mm}$ & 0 & 100 & 0 & 545 \\
\hline Nominal grain size $7 \mathrm{~mm}$ & 0 & 0 & 100 & 857 \\
\hline
\end{tabular}




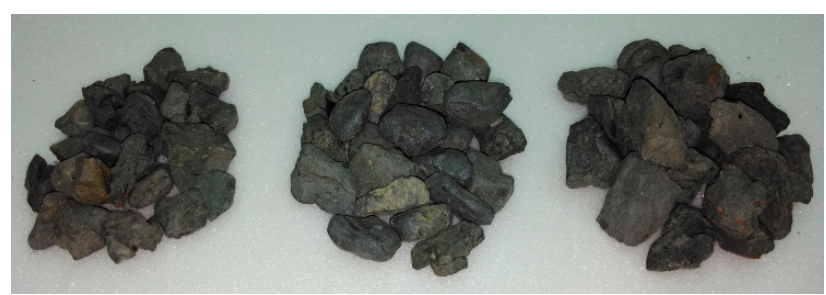
(a) $7 \mathrm{~mm}$
(b) $11 \mathrm{~mm}$
(c) $16 \mathrm{~mm}$

Figure 1. Particle shape of lightweight aggregate (LWA).

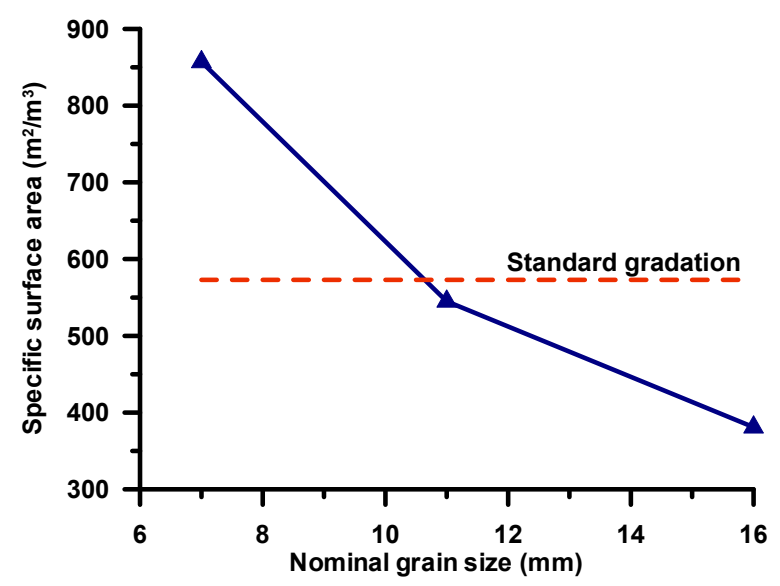

Figure 2. Relationship between grain size and the specific surface area (SSA) of aggregates.

Two water-cement ratios (w/c), 0.4 and 0.7, were selected to investigate the aggregate grade impact on the concrete properties. Under a fixed w/c, the amount of mortar, and aggregate volume, the aggregate grade was the only variable that was changed. The aggregates' grade effect on the concrete properties was explored. The differences between LWAC and NWC were analyzed and compared. The LWAC and NWC test mix-proportions are shown in Tables 3 and 4. In these tables, L indicates LWAC while N means NWC, and 0.4 indicates w/c. S represents the standard aggregate grade that met the ASTM C33 or ASTM C330 specification, and 16 means aggregates with a nominal grain size of $16 \mathrm{~mm}$, respectively. The lightweight aggregates were oven-dried and pre-wet before mixing (the amount of 30 min water absorption was used).

Table 3. Mix proportions of lightweight aggregate concrete (LWAC) $\left(\mathrm{kg} / \mathrm{m}^{3}\right)$.

\begin{tabular}{|c|c|c|c|c|c|c|c|}
\hline \multirow{2}{*}{ Item } & \multirow{2}{*}{ w/c } & \multirow{2}{*}{ Cement } & \multirow{2}{*}{ Water } & \multirow{2}{*}{$\begin{array}{l}\text { Normal Weight } \\
\text { Fine Aggregates }\end{array}$} & \multicolumn{3}{|c|}{ Lightweight Coarse Aggregates (Oven-Dried) } \\
\hline & & & & & $19-12.5 \mathrm{~mm}$ & $12.5-9.5 \mathrm{~mm}$ & $9.5-4.75 \mathrm{~mm}$ \\
\hline L0.7-S & \multirow{4}{*}{0.7} & \multirow{4}{*}{290} & \multirow{4}{*}{202} & \multirow{4}{*}{721} & 239 & 179 & 183 \\
\hline L0.7-16 & & & & & 598 & 0 & 0 \\
\hline L0.7-11 & & & & & 0 & 597 & 0 \\
\hline L0.7-7 & & & & & 0 & 0 & 609 \\
\hline L0.4-S & \multirow{4}{*}{0.4} & \multirow{4}{*}{480} & \multirow{4}{*}{194} & \multirow{4}{*}{667} & 221 & 165 & 169 \\
\hline L0.4-16 & & & & & 552 & 0 & 0 \\
\hline L0.4-11 & & & & & 0 & 551 & 0 \\
\hline L0.4-7 & & & & & 0 & 0 & 562 \\
\hline
\end{tabular}


Table 4. Mix proportions of normal-weight concrete (NWC) $\left(\mathrm{kg} / \mathrm{m}^{3}\right)$.

\begin{tabular}{|c|c|c|c|c|c|c|c|}
\hline \multirow{2}{*}{ Item } & \multirow{2}{*}{ w/c } & \multirow{2}{*}{ Cement } & \multirow{2}{*}{ Water } & \multirow{2}{*}{$\begin{array}{l}\text { Normal Weight } \\
\text { Fine Aggregates }\end{array}$} & \multicolumn{3}{|c|}{ Normal Weight Coarse Aggregates } \\
\hline & & & & & $19-12.5 \mathrm{~mm}$ & $12.5-9.5 \mathrm{~mm}$ & $9.5-4.75 \mathrm{~mm}$ \\
\hline N0.7-S & \multirow{4}{*}{0.7} & \multirow{4}{*}{290} & \multirow{4}{*}{202} & \multirow{4}{*}{721} & 419 & 342 & 342 \\
\hline N0.7-16 & & & & & 1103 & 0 & 0 \\
\hline N0.7-11 & & & & & 0 & 1103 & 0 \\
\hline N0.7-7 & & & & & 0 & 0 & 1103 \\
\hline N0.4-S & \multirow{4}{*}{0.4} & \multirow{4}{*}{480} & \multirow{4}{*}{194} & \multirow{4}{*}{667} & 387 & 316 & 316 \\
\hline N0.4-16 & & & & & 1019 & 0 & 0 \\
\hline N0.4-11 & & & & & 0 & 1019 & 0 \\
\hline N0.4-7 & & & & & 0 & 0 & 1019 \\
\hline
\end{tabular}

\section{Results and Discussion}

To investigate the effects of aggregate grade on the concrete properties, various experiments on the concrete freshness properties, hardened properties, and durability properties were conducted. The freshness concrete properties are tested in slump, air-content, and unit weight tests, and the hardened concrete property is tested in a compressive strength test. These tests followed the corresponding ASTM specifications. The strength values were derived from the average value of five cylindrical specimens $(\varphi 150 \times 300 \mathrm{~mm})$ after 28 days of standard curing. Concrete durability property tests included permeability and electrical resistance. The permeability test (Figure 3) used $10 \mathrm{~kg} / \mathrm{cm}^{2}$ of water pressure upon the top surface of oven-dried specimens $(\varphi 150 \times 300 \mathrm{~mm})$ for three hours. The electrical resistance test (Figure 4) measured four electrical resistance values for each cylindrical specimen $(\varphi 150 \times 300 \mathrm{~mm})$. The average values were then calculated. All test results are shown in Table 5.

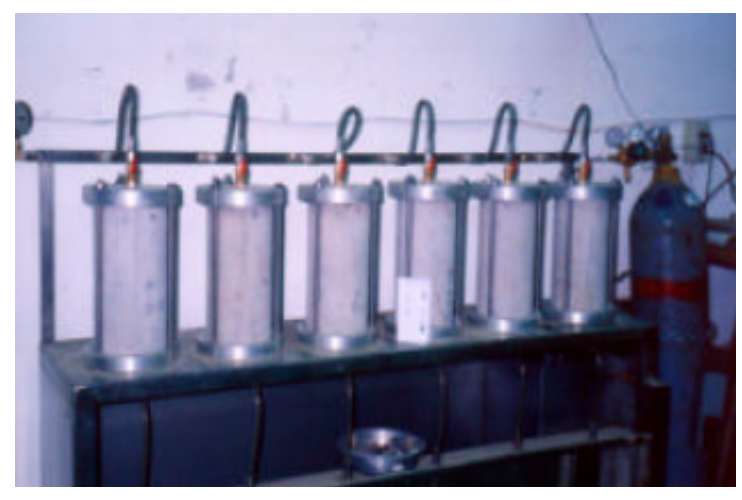

Figure 3. Permeability test.

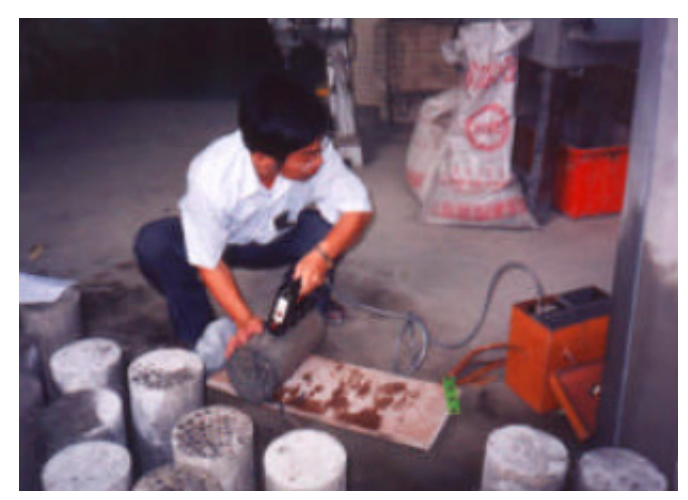

Figure 4. Electrical resistance test. 
Table 5. Engineering properties of concrete.

\begin{tabular}{|c|c|c|c|c|c|c|}
\hline \multirow[b]{2}{*}{ Item } & \multicolumn{3}{|c|}{ Fresh Concrete } & \multirow{2}{*}{$\begin{array}{c}\text { Hardened Concrete } \\
\text { Compressive } \\
\text { Strength (MPa) } \\
\end{array}$} & \multicolumn{2}{|c|}{ Durability } \\
\hline & $\begin{array}{l}\text { Slump } \\
(\mathrm{mm})\end{array}$ & $\begin{array}{c}\text { Air Content } \\
(\%)\end{array}$ & $\begin{array}{l}\text { Unit Weight } \\
\left(\mathrm{kg} / \mathrm{m}^{3}\right)\end{array}$ & & $\begin{array}{c}\text { Permeant } \\
\text { Volume }\left(\mathrm{cm}^{3}\right)\end{array}$ & $\begin{array}{c}\text { Electrical } \\
\text { Resistance }(\mathrm{k} \Omega-\mathrm{cm})\end{array}$ \\
\hline L0.7-S & 180 & 2.1 & 1857 & 23.8 & 16 & 15.9 \\
\hline L0.7-16 & 220 & 1.5 & 1874 & 21.9 & 17 & 15.9 \\
\hline L $0.7-11$ & 180 & 1.9 & 1852 & 24.5 & 19 & 15.9 \\
\hline L $0.7-7$ & 130 & 2.1 & 1901 & 26.3 & 15 & 16.5 \\
\hline N0.7-S & 160 & 1.0 & 2351 & 24.0 & 31 & 14.1 \\
\hline N0.7-16 & 200 & 0.8 & 2361 & 21.4 & 26 & 15.9 \\
\hline N0.7-11 & 130 & 1.5 & 2349 & 23.1 & 33 & 14.1 \\
\hline N0.7-7 & 70 & 1.7 & 2344 & 23.9 & 41 & 12.9 \\
\hline L0.4-S & 60 & 2.5 & 1937 & 44.8 & 13 & 23.1 \\
\hline L0.4-16 & 65 & 2.1 & 1925 & 38.6 & 14 & 21.9 \\
\hline L0.4-11 & 60 & 2.2 & 1936 & 43.7 & 14 & 24.9 \\
\hline L $0.4-7$ & 45 & 2.2 & 1943 & 57.8 & 12 & 24.6 \\
\hline N0.4-S & 35 & 2.2 & 2399 & 53.1 & 14 & 20.4 \\
\hline N0.4-16 & 60 & 1.7 & 2399 & 52.0 & 12 & 20.7 \\
\hline N0.4-11 & 45 & 1.6 & 2382 & 50.6 & 12 & 19.2 \\
\hline N0.4-7 & 25 & 1.9 & 2387 & 54.2 & 14 & 18.6 \\
\hline
\end{tabular}

\subsection{Influence of Aggregates' Gradation on the Properties of Fresh Concrete}

The mixing duration was two minutes. The slump and air content tests proceeded after mixing for eight minutes. The slump test results are shown in Table 5 and Figure 5. From Table 5, it can be seen that the LWAC slumps were in the range of $130 \mathrm{~mm}$ to $220 \mathrm{~mm}$. The NWC slumps were in the range of $70 \mathrm{~mm}$ to $200 \mathrm{~mm}$ when the $\mathrm{w} / \mathrm{c}=0.7$. As for the $\mathrm{w} / \mathrm{c}=0.4$, the LWAC slumps were within $45 \mathrm{~mm}$ to $65 \mathrm{~mm}$, while the NWC slumps were within $25 \mathrm{~mm}$ to $60 \mathrm{~mm}$.

Figure 5a shows a LWAC slump in which $7 \mathrm{~mm}$ uniform size aggregates were $130 \mathrm{~mm}$ when the $\mathrm{w} / \mathrm{c}$ is 0.7 . The slump increased to $220 \mathrm{~mm}$ as the size of the aggregate changed to $16 \mathrm{~mm}$. The increment was about $70 \%$. NWC exhibited the same trend. The workability of the concrete was obviously affected by the aggregate grade. Figure 2 shows that the SSA of the aggregates and the slump are inversely proportional to grain size. The concrete slump becomes larger as well. The same tendency appeared at the low water-cement ratio $(w / c=0.4$, shown in Figure $5 b)$. The main reason is that the amount of paste adhering to the aggregate surface becomes reduced as the SSA decreases. When the total volume of paste is fixed, the paste provided for flowing increases relatively. Therefore, the workability of the concrete becomes better. This is not so obvious at lower water-cement ratios because of the high paste consistency in the concrete.

The differences between LWAC and NWC were further compared. Under the same mix proportions, the LWAC slump was larger than that of NWC slump. The possible reason is that the coarse aggregates of LWAC were oven-dried. Thirty minutes of lightweight aggregate absorption was used while mixing. The redundant water, which could not be completely absorbed by the lightweight aggregates at the beginning of the mixing process, transformed into mixing water. Therefore, the workability of LWAC was enhanced. Moreover, the shape of lightweight aggregates was much rounder than that of normal weight aggregates. Therefore, the resistance was relatively low when flowing. Combining the characteristics of lightweight aggregates mentioned above, all cause a slightly better LWAC workability than that for NWC under the same mix proportions.

According to the air content test result in Table 5, the air contents of LWAC were in the range of $1.5 \%$ to $2.5 \%$. Compared to the air content in NWC with the same aggregates grade, the air content of LWAC was about $0.4-1.1 \%$ higher than that of NWC. The major cause is the great quantity of pores existing on the shell of lightweight aggregates. The air content measurement for concrete is the pressure method, so that the value might be highly estimated because of the influence from such surface pores. Therefore, the air content of LWAC is higher than that of NWC. 
The specific gravity of normal-weight aggregates was about 2.65 for each grain size. The specific gravity of lightweight aggregates was about 1.46 for each grain size. By virtue of the similar aggregate specific gravity for each size of aggregate, the influence on the unit weight of aggregates' grade was not obvious for both LWAC and NWC. Comparing the unit weight of LWAC and NWC, LWAC, which uses the expanded shale lightweight aggregates, is about $20 \%$ lower than NWC on average. The unit weight of LWAC depends on the specific gravity and amount of lightweight aggregate. If the lightweight aggregates with plenty of pores and low density were used, the unit weight of the concrete could be certainly reduced.

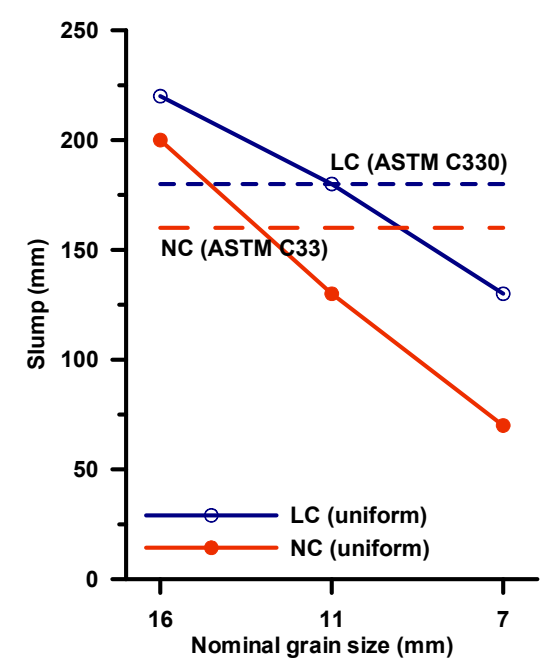

(a) $\mathrm{w} / \mathrm{c}=0.7$

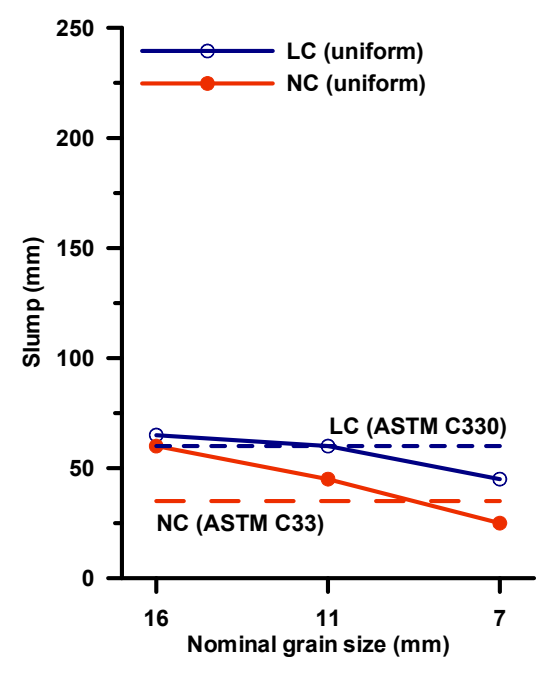

(b) $\mathrm{w} / \mathrm{c}=0.4$.

Figure 5. Slump of normal-weight concrete (NWC) and lightweight aggregate concrete (LWAC).

\subsection{Influence of Aggregates' Gradation on the Properties of Concrete Strength}

As shown in Table 5, the compressive strength of LWAC with various mix proportions was approximately $22 \mathrm{MPa}$ to $26 \mathrm{MPa}$ when the $\mathrm{w} / \mathrm{c}$ is 0.7 . For NWC with the same $\mathrm{w} / \mathrm{c}$, the compressive strength was about $21 \mathrm{MPa}$ to $24 \mathrm{MPa}$, which was close to that of LWAC. However, the compressive strength of LWAC with various mix proportions was approximately $39 \mathrm{MPa}$ to $58 \mathrm{MPa}$ when the $\mathrm{w} / \mathrm{c}$ is 0.4 , while that of NWC was about $51 \mathrm{MPa}$ to $56 \mathrm{MPa}$. The discrepancy between them was considerably evident.

Figure 6 shows the relationship between the concrete compressive strength with uniform size aggregates and that of concrete with standard-grade aggregates (fit in with the ASTM specification). As shown in the figure, the compressive strength of LWAC which uses $7 \mathrm{~mm}$ uniform-sized aggregates is $11 \%$ higher than that of LWAC with standard gradation aggregates when the w/c is 0.7 . Furthermore, the difference approaches $29 \%$ when the $\mathrm{w} / \mathrm{c}$ is 0.4 . The compressive strength of NWC which uses uniform size aggregates was mostly lower than that of NWC with standard-grade aggregates with high or low w/c. The values were in the range of $89 \%$ to $102 \%$. This indicates that NWC with standard gradation aggregates possesses comparatively higher compressive strength. However, LWAC with standard gradation aggregates does not exhibit better compressive strength.

There is a tendency for the compressive strength of LWAC increases as the aggregate grain size decreases, this appeared regardless of the $\mathrm{w} / \mathrm{c}$ value. The larger SSA the aggregates possess, the higher compressive strength of the concrete. This is especially conspicuous under the low w/c. Like composite material, lightweight aggregate is the weak-phased material in LWAC (especially at the low $\mathrm{w} / \mathrm{c}$ ). Under the same total volume of aggregates, the number of aggregate particles increase as the grain size of the aggregates decreases. The distribution of weak-phased material in concrete 
tends towards uniform. The uniformity of concrete is consequently improved, so that the concrete represents preferable strength.

Furthermore, at the low water-cement ratio $(\mathrm{w} / \mathrm{c}=0.4)$, the difference of compressive strength with varied gradation is obvious. This is because the particle strength and elastic modulus of lightweight aggregates are both lower than those of mortar, so that the strength behavior of LWAC is mainly controlled by aggregates [14-22]. Hence the influence of aggregate gradation on the strength of concrete is extremely obvious. The strength and elastic modulus of natural aggregate are higher than that of mortar, and the achievable strength of NWC is mainly predominated by mortar. The aggregates merely present the reinforced particles in concrete. Therefore, the effect of the variation of aggregates' gradation on the concrete strength is not evident (shown in Figure 6b). This phenomenon occurs in LWAC with a high w/c, as well (shown in Figure 6a). The strength of mortar reduces as the w/c is high. The strength of lightweight aggregates could be higher than that of mortar at this time, and the lightweight aggregates possess the strength properties like natural aggregates. The lightweight aggregates perform the reinforced particles in LWAC, and the strength of concrete tends to be decided by mortar. For this reason, the strength of LWAC and NWC is almost identical (as w/c $=0.7$ ) under the same mix condition. Furthermore, the influence of aggregate gradation has a similar tendency.

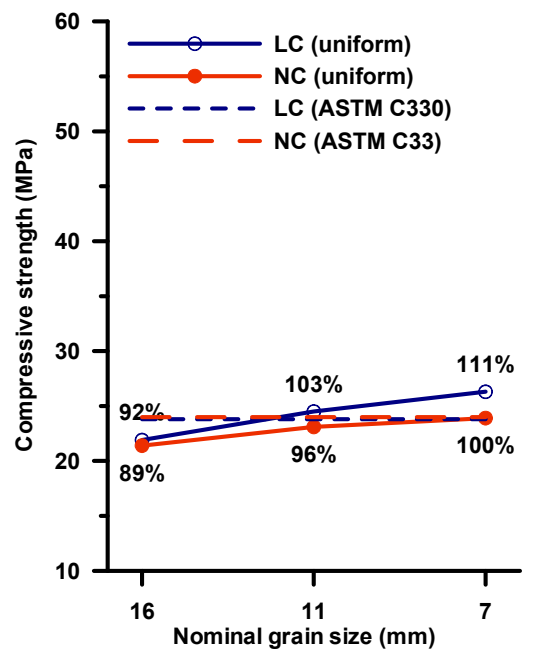

(a) $\mathrm{w} / \mathrm{c}=0.7$.

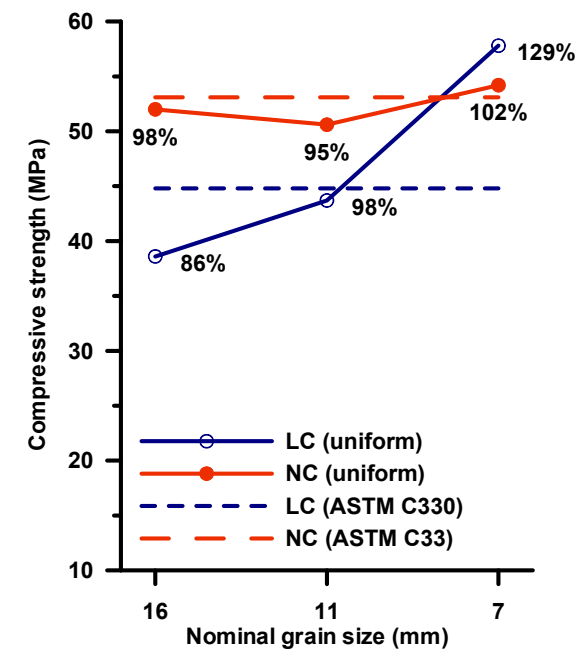

(b) $\mathrm{w} / \mathrm{c}=0.4$.

Figure 6. Compressive strength of NWC and LWAC.

As a result, the standard grade of aggregates that follows the specification requirement should still be adopted in NWC and high $\mathrm{w} / \mathrm{c}$ ratio LWAC for improving the characteristics of strength and workability. In LWAC proportioning (low w/c), if the major concern is concrete strength, the standard gradation advised by ASTM could not be followed.

From the discussion mentioned above, LWAC with lightweight aggregate of small grain size and uniform grade represents comparatively superior strength behavior in the high-strength (low w/c) concrete.

The quality concrete possesses low unit weight and holds the high compressive strength at the same time. If the ratio between compressive strength and unit weight of concrete is larger, the economic benefits that the concrete structure provides could be enhanced. Strength efficiency is defined as the compressive strength provided by concrete per unit weight in this research. Figure 7 shows the relationship between the aggregate grain size and strength efficiency of concretes. The strength efficiency of LWAC with high water-cement ratio $(\mathrm{w} / \mathrm{c}=0.7)$ is approximately 0.012 to 0.013 . Comparing with that of NWC which is about 0.009 to 0.010 , the value is probably $30 \%$ higher. The average of the strength efficiency of LWAC with a low water-cement ratio $(\mathrm{w} / \mathrm{c}=0.4)$ is mostly 
higher than that of NWC, but the diversity is comparatively unobvious under the larger grain size condition. The influence of the aggregates' grade is considered. It can be seen from the figure that the strength efficiency increased as the grain size of aggregates decrease in substance. For NWC, strength efficiency with uniform grain size aggregates is mostly lower than that of standard gradation aggregates. However, the strength efficiency of LWAC with small uniform grain size aggregates is conspicuously higher than that with standard-grade aggregates.

Knowing from the test results mentioned above, both compressive strength and strength efficiency of LWAC with a uniform aggregate grain size less than $11 \mathrm{~mm}$ are evidently excellent compared to that of standard-grade aggregates. However, this tendency does not occur in NWC. Therefore, this research recommends that the aggregates gradation requirement of LWAC should be distinct from that of NWC. Following the standard grade suggested by ASTM is optional.

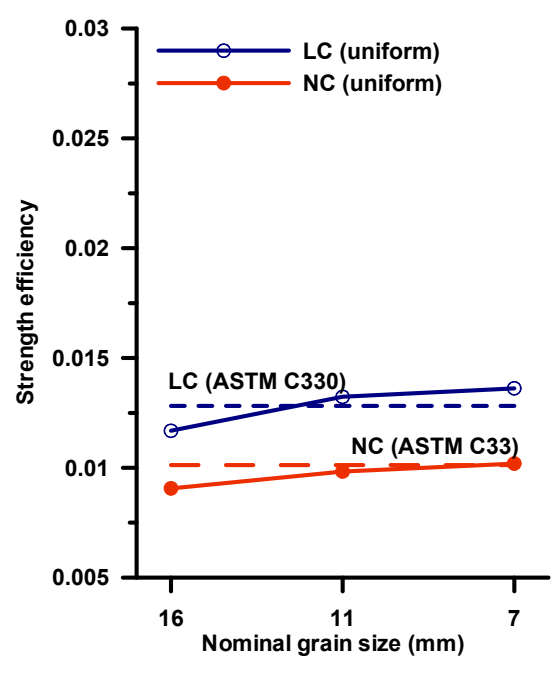

(a) $\mathrm{w} / \mathrm{c}=0.7$.

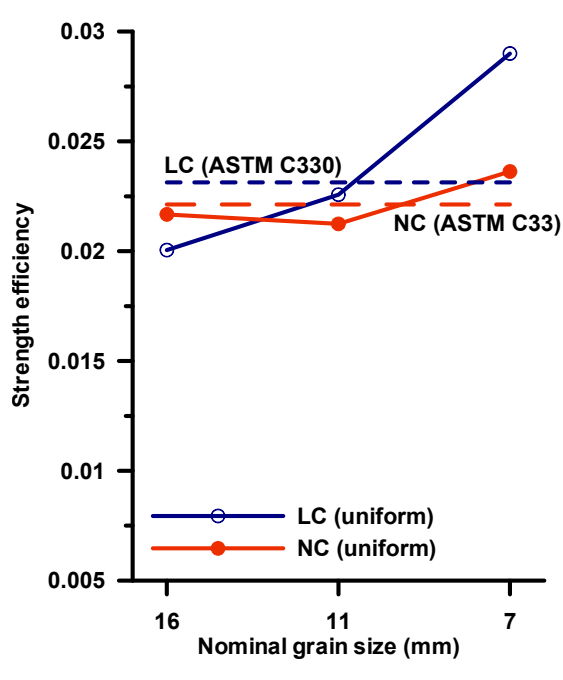

(b) $\mathrm{w} / \mathrm{c}=0.4$.

Figure 7. Strength efficiency of NWC and LWAC.

\subsection{Influences of Aggregates' Gradation on the Durability of Concrete}

Test results for three-hour water permeation of LWAC and NWC are shown in Table 5 and Figure 8. Water permeation of LWAC with the standard grade $\left(\mathrm{SSA}=573 \mathrm{~m}^{2} / \mathrm{m}^{3}\right)$ is $16 \mathrm{~cm}^{3}$ at $0.7 \mathrm{w} / \mathrm{c}$, while the value of NWC is $31 \mathrm{~cm}^{3}$. Water permeation of LWAC is obviously smaller than that of NWC. It can also be found that the influence of the variation in coarse aggregates' gradation on the permeability of NWC is comparatively apparent. When the SSA of NWC increases, water permeation increases as well. However, the effect of variation of coarse aggregates' gradation on the permeability of LWAC is not prominent.

Water permeation inside the concrete predominantly occurs via the bonding interface of aggregates and mortar. For NWC, the smaller grain size aggregates have, the more SSA is. So that the path for water to pass through is increased, the permeant volume increases too. For example, the permeant volume for NWC with $7 \mathrm{~mm}$ grain size aggregates approaches $41 \mathrm{~cm}^{3}$. A comparatively superior interface zone forms because the surface pores of lightweight aggregates could be provided for mortar to lock [23,24]. Therefore, the permeant volume for LWAC is less regardless of variations in aggregate gradation. That is to say that LWAC possesses comparatively preferable anti-permeability.

Nevertheless, the effect of variation of coarse aggregates gradation on the permeability of both LWAC and NWC is not obvious at $0.4 \mathrm{w} / \mathrm{c}$ (see Figure $8 \mathrm{~b}$ ). The main reason is that the mortar strength is considerably high. Whether using normal weight aggregates or lightweight aggregates, the interface zone between the aggregates and mortar was substantially strengthened. The influence of 
the foregoing interface locking effect will be virtually eliminated. Hence, NWC and LWAC represent a similar permeation behavior regardless of various gradations.

The electrical resistance test results for LWAC and NWC are shown in Table 5 and Figure 9. The results show that the electrical resistances of LWAC are all slightly higher than that of NWC. It is especially conspicuous at a low water-cement ratio $(\mathrm{w} / \mathrm{c}=0.4)$.

The electrical resistance depends on the water path to conduct electricity inside the concrete. Due to the better bonding between the surface pores of lightweight aggregates and mortar, LWAC possesses a comparatively better interface zone. A part of the water path to conduct electricity between the interface of mortar and aggregates was obstructed so that the electrical resistance of LWAC is higher than that of NWC. When the uniform grain size was used, the electrical resistance of LWAC increased as the grain size decreased. On the contrary, the electrical resistance of NWC decreased as the grain size decreased. The primary reason is that the SSA of natural aggregates increased as the grain size decreased. It brings on the increment of the path to conduct electricity, following with the decrement of the electrical resistance of concrete. However, mortar of LWAC is comparatively dense [23-27]; as a result electrical resistance increased.

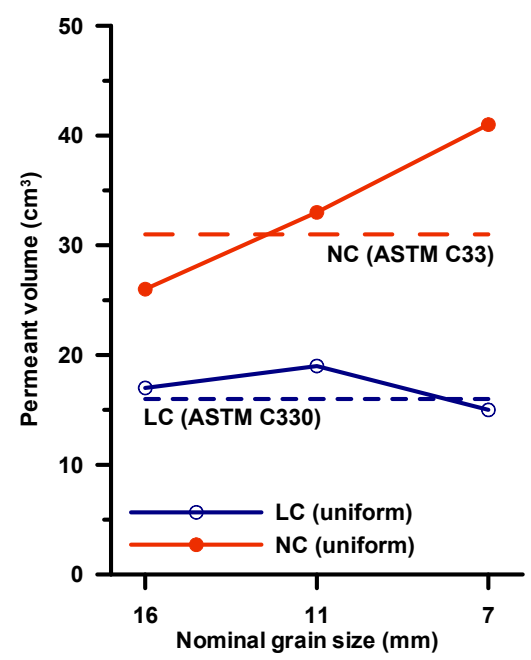

(a) $\mathrm{w} / \mathrm{c}=0.7$.

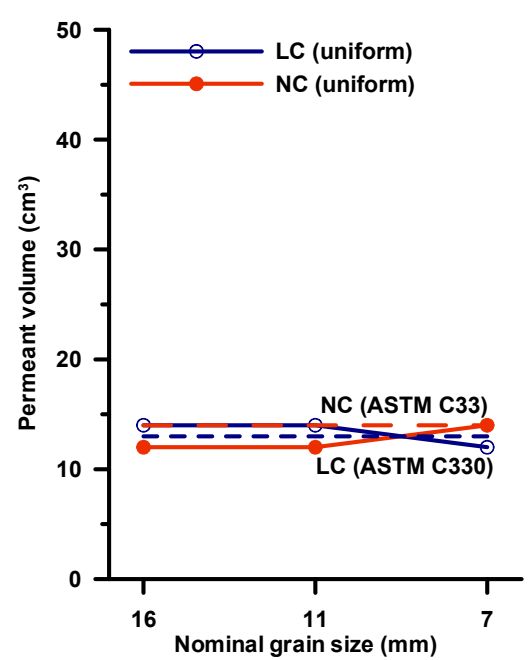

(b) $\mathrm{w} / \mathrm{c}=0.4$.

Figure 8. Permeability of NWC and LWAC.

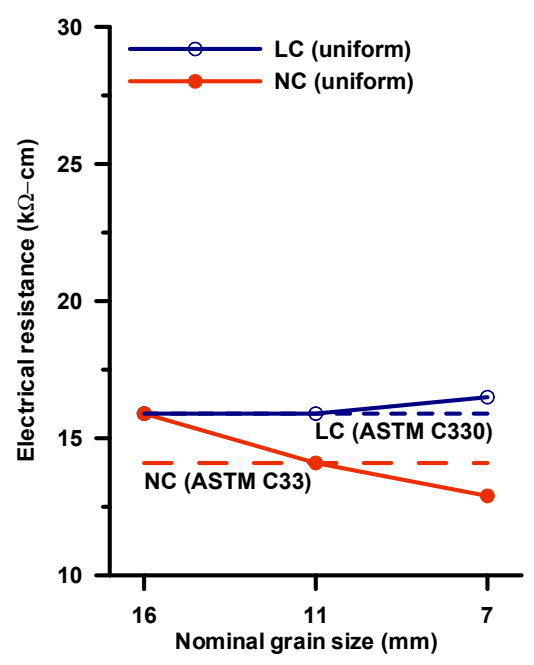

(a) $\mathrm{w} / \mathrm{c}=0.7$.

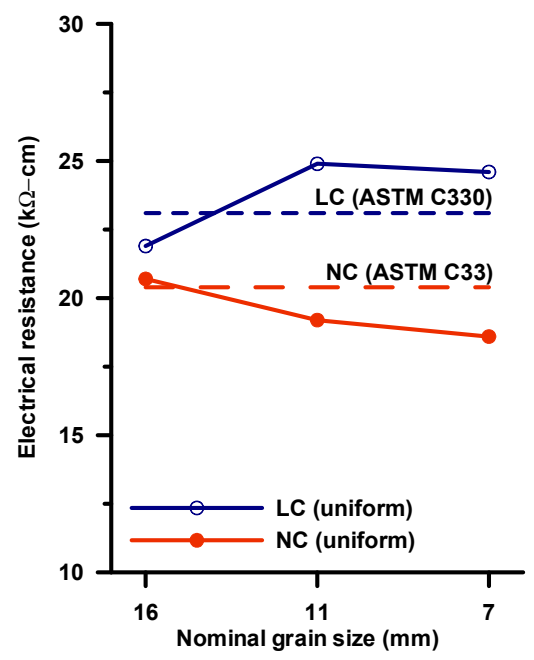

(b) $\mathrm{w} / \mathrm{c}=0.4$.

Figure 9. Electrical resistance of NWC and LWAC. 


\section{Conclusions}

Our conclusions from this research are as follows:

1. Whether NWC or LWAC, the larger SSA coarse aggregates provide better concrete workability. Workability decreases when aggregates are of uniform grade and small grain size.

2. LWAC used lightweight aggregates with uniform grade and less than $11 \mathrm{~mm}$ grain size obtained higher compressive strength than that using standard grade aggregates. It is advantageous to increase the compressive strength by using smaller grain size aggregates. However, this tendency does not occur in NWC.

3. According to the representations of compressive strength, this research recommends that the requirement for aggregates grade for LWAC should not be the same as that of NWC.

4. In LWAC proportioning (low $\mathrm{w} / \mathrm{c}$ ), if the major concern is concrete strength, the standard gradation advised by ASTM could not be followed.

5. The interface zone between mortar and aggregates of LWAC is comparatively dense. The water permeation of LWAC will be less, and the electrical resistance will be higher than those of NWC. The permeability and electrical resistance of LWAC will be improved as the grain size decreases.

Author Contributions: Conceptualization, H.-J.C. and C.-H.W.; Methodology, H.-J.C.; Validation, H.-J.C. and C.-H.W.; Formal Analysis, H.-J.C. and C.-H.W.; Investigation, H.-J.C.; Resources, H.-J.C.; Data Curation, C.-H.W.; Writing-Original Draft Preparation, H.-J.C.; Writing-Review \& Editing, H.-J.C. and C.-H.W.; Visualization, H.-J.C. and C.-H.W.; Supervision, H.-J.C.; Project Administration, H.-J.C.

Funding: This research received no external funding.

Acknowledgments: The authors would like to thank Kuo-Chang Jane for his useful advice.

Conflicts of Interest: The authors declare no conflict of interest.

\section{References}

1. China National Standards, CNS 3691 A2046, Lightweight Aggregates for Structural Concrete. 1974. Available online: https:/ / www.bsmi.gov.tw/wSite/mp?mp=2 (accessed on 8 August 2018).

2. DIN 1045, Befon und stahlleichtbeton, Bemessmmg und Ausfuehrung. 1970. Available online: https://www. umwelt-online.de/recht/bau/din/4219_ges.htm (accessed on 8 August 2018).

3. ASTM C330/C330M-17a, Standard Specification for Lightweight Aggregates for Structural Concrete. 2017. Available online: https:/ /www.astm.org/Standards/C330.htm (accessed on 8 August 2018).

4. He, Y.; Zhang, X.; Zhang, Y. Effects of Particle Characteristics of Lightweight Aggregate on Mechanical Properties of Lightweight Aggregate Concrete. Constr. Build. Mater. 2014, 72, 270-282. [CrossRef]

5. Zaetang, Y.; Wongsa, A.; Sata, V. Use of Lightweight Aggregates in Pervious Concrete. Constr. Build. Mater. 2013, 48, 585-591. [CrossRef]

6. Shafigh, P.; Jumaat, M.Z.; Mahmud, H.B.; Hamid, N.A.A. Lightweight Concrete Made from Crushed Oil Palm Shell: Tensile Strength and Effect of Initial Curing on Compressive Strength. Constr. Build. Mater. 2012, 27, 252-258. [CrossRef]

7. Bogas, J.A.; Gomes, M.G.; Real, S. Capillary Absorption of Structural Lightweight Aggregate Concrete. Mater. Struct. 2015, 48, 2869-2883. [CrossRef]

8. Chung, S.Y.; Elrahman, M.A.; Stephan, D. Effect of Different Gradings of Lightweight Aggregates on the Properties of Concrete. Appl. Sci. 2017, 7, 585. [CrossRef]

9. Khademi, F.; Akbari, M.; Jamal, S.M. Prediction of Compressive Strength of Concrete by Data-Driven Models. Civ. Eng. 2015, 5, 16-23. [CrossRef]

10. Nikoo, M.; Torabian, M.F.; Sadowski, L. Prediction of Concrete Compressive Strength by Evolutionary Artificial Neural Networks. Adv. Mater. Sci. Eng. 2015, 2015, 849126. [CrossRef]

11. Sarıdemir, M. Predicting the Compressive Strength of Mortars Containing Metakaolin by Artificial Neural Networks and Fuzzy Logic. Adv. Eng. Softw. 2009, 40, 920-927. [CrossRef]

12. Khademi, F.; Akbari, M.; Jamal, S.M.; Nikoo, M. Multiple Linear Regression, Artificial Neural Network, and Fuzzy Logic Prediction of 28 Days Compressive Strength of Concrete. Front. Struct. Civ. Eng. 2017, 11, 90-99. [CrossRef] 
13. Singh, B.G. Specific Surface of Aggregate Applied to Mix Proportioning. ACI J. Proc. 1959, 55, 893-901.

14. Zhang, M.H.; Gjvorv, O.E. Mechanical Properties of High-Strength Lightweight Concrete. ACI Mater. J. 1991, $88,240-247$.

15. Chen, H.J.; Yen, T.; Lia, T.P.; Huang, Y.L. Determination of the Dividing Strength and its Relation to the Concrete Strength in Lightweight Aggregate Concrete. Cem. Concr. Comp. 1999, 21, 29-37. [CrossRef]

16. Chen, H.J.; Yen, T.; Chen, K.H. Evaluating Elastic Modulus of Lightweight Aggregate. ACI Mater. J. 2003, 100, 108-113.

17. Wu, T.; Wei, H.; Liu, X.; Xing, G.H. Factors Influencing the Mechanical Properties of Lightweight Aggregate Concrete. Indian J. Eng. Mater. Sci. 2016, 23, 301-311.

18. Zhang, L.H.; Zhang, Y.S.; Liu, C.B.; Liu, L.B.; Tang, K.J. Study on Microstructure and Bond Strength of Interfacial Transition Zone between Cement Paste and High-Performance Lightweight Aggregates Prepared from Ferrochromium Slag. Constr. Build. Mater. 2017, 142, 31-41. [CrossRef]

19. Shafigh, P.; Jumaat, M.Z.; Mahmud, H. Effect of Replacement of Normal Weight Coarse Aggregate with Oil Palm Shell on Properties of Concrete. Arab. J. Sci. Eng. 2012, 37, 955-964. [CrossRef]

20. Rathish, K.P.; Krishna, R.M.V. A Study on the Effect of Size of Aggregate on the Strength and Sorptivity Characteristics of Cinder based Light Weight Concrete. Res. J. Eng. Sci. 2012, 1, 27-35.

21. Malesev, M.; Radonjanin, V.; Lukic, I.; Bulatovic, V. The Effect of Aggregate, Type and Quantity of Cement on Modulus of Elasticity of Lightweight Aggregate Concrete. Arab. J. Sci. Eng. 2014, 39, 705-711. [CrossRef]

22. Shafigh, P.; Ghafari, H.; Mahmud, H.B.; Jumaat, M.Z. A Comparison Study of the Mechanical Properties and Drying Shrinkage of Oil Palm Shell and Expanded Clay Lightweight Aggregate Concretes. Mater. Des. 2014, 60, 320-327. [CrossRef]

23. Wasserman, R.; Bentur, A. Interfacial Interactions in Lightweight Aggregate Concrete and their Influence on the Concrete Strength. Cem. Concr. Comp. 1996, 18, 67-76. [CrossRef]

24. Kohno, K.; Okamoto, T.; Isikawa, Y.; Sibata, T.; Mori, H. Effects of Artificial Lightweight Aggregate on Autogenous Shrinkage of Concrete. Cem. Concr. Res. 1999, 29, 611-614. [CrossRef]

25. Youm, K.S.; Moon, J.; Cho, J.Y.; Kim, J.J. Experimental Study on Strength and Durability of Lightweight Aggregate Concrete Containing Silica Fume. Constr. Build. Mater. 2016, 114, 517-527. [CrossRef]

26. Shafigh, P.; Nomeli, M.A.; Alengaram, U.J.; Mahmud, H.B.; Jumaat, M.Z. Engineering Properties of Lightweight Aggregate Concrete Containing Limestone Powder and High Volume Fly Ash. J. Clean. Prod. 2016, 135, 148-157. [CrossRef]

27. Farahani, J.N.; Shafigh, P.; Alsubari, B.; Shahnazar, S.; Mahmud, H.B. Engineering Properties of Lightweight Aggregate Concrete Containing Binary and Ternary Blended Cement. J. Clean. Prod. 2017, 149, 976-988. [CrossRef]

(C) 2018 by the authors. Licensee MDPI, Basel, Switzerland. This article is an open access article distributed under the terms and conditions of the Creative Commons Attribution (CC BY) license (http://creativecommons.org/licenses/by/4.0/). 